\title{
Competing Constraints on Vorfeldbesetzung in German*
}

\author{
Augustin Speyer \\ University of Pennsylvania, Philadelphia \\ speyer@babel. ling . upenn. edu
}

\begin{abstract}
The filling of the 'Vorfeld' in German sentences is basically obligatory; which constituent, however, actually moves to the Vorfeld is underdetermined by syntax and thus governed presumably by discourse factors. Coming from English, there are certain competing expectations one could have: either the topic - more specifically, the backward-looking center — of a sentence is moved to the Vorfeld, or an element in a poset relationship to a set mentioned in the previous discourse, or elements with other functions, such as the exposition of brand-new information or the setting of a scene. A study of a corpus of texts of different stylistic levels showed that indeed all elements expected to appear in the Vorfeld are eligible for Vorfeld-movement, but that there is a strict ranking. Preferred Vorfeld-fillers are phrases containing brand-new information as well as scene-setting elements; only if no such elements are present can elements in a poset relationship with some previously mentioned set be moved to the Vorfeld. Finally, if such elements are not present either, backwardlooking centers can move to the Vorfeld. Backward-looking centers have, for this reason, a relatively poor quota among Vorfeld-fillers, namely around 50\%.
\end{abstract}

\section{Introduction}

The German language, as is well known, is subject to the verb-second constraint. This involves compulsory movement of the verb to $\mathrm{C}^{\circ}$ and of some other constituent to Spec,CP (Vikner 1995). Spec,CP is in the German literature often referred to as Vorfeld (Grewendorf, Hamm, Sternefeld 1987; Reis 1987:147f.). Which constituent actually is moved to Spec,CP is underdetermined by syntax. It is consequently reasonable to assume that movement to Spec,CP is governed by discourse requirements.

What could these discourse requirements be? In order to address this question it is useful to have a look at a closely related language, let us say

\footnotetext{
* A version of this paper was presented at the Workshop for Dislocated Elements in Discourse at the Zentrum für Allgemeine Sprachwissenschaft in Berlin (28-30 November 2003). I wish to thank the participants of this workshop, especially Werner Frey, for indicating places where this paper could be improved, which I hope to incorporate into future work. I also want to express my warmest thanks to Ellen Prince and Marga Reis for their valuable comments and suggestions.
} 
English, to see if there are phenomena which are comparable to German Vorfeldbesetzung (= movement to Spec, $\mathrm{CP}$ ) in that they involve nonsyntactically determined preposing of a constituent. In contrast to German, these English cases would involve non-canonical word-order, since English is not subject to the verb-second constraint, as German is, but instead obeys the constraint that the subject must precede the verb and should be the first constituent in the clause. This is nothing more than a consequence of the fact that English declarative main clauses (questions are not relevant for the purposes of this paper) do not have a $\mathrm{CP}$ as highest projection but only an IP. Since the subject receives case only after it has been moved to Spec,IP, it follows that this position is reserved for the subject and thus the subject ends up automatically as the first constituent of a (normal) main clause.

But in English there are still a number of constructions which involve noncanonical word order, i.e. where the subject is not the first constituent of the clause. Two of them are inversion and topicalization.

Note that both constructions are different from each other in that inversion in English shows a surface word order like

$$
\begin{aligned}
& \mathrm{X}-\mathrm{V}-\mathrm{S} \\
& (\mathrm{V}=\text { Verb; } \mathrm{S}=\text { Subject; } \mathrm{X}, \mathrm{Y}=\text { any constituent })
\end{aligned}
$$

whereas topicalization shows a word order like

$$
\mathrm{X}-\mathrm{S}-\mathrm{V}
$$

They both differ from the canonical word order which requires both that the subject be before the verb and that the subject be the first element in the sentence. The difference, to summarize, is that in both cases there is some non-subject element in the first position in the sentence.

This goes for English. German has, in contrast to English, not the subjectverb constraint, but the V2 constraint. This means that for German the equivalents of English inversion and English topicalization must have the same structure, namely:

$$
\mathrm{X}-\mathrm{V}-\mathrm{S}
$$

since the only thing which is determined is the position of the verb, which must appear as the second constituent in the clause.

This is, however, only a subcase of the more general

$$
\mathrm{X}-\mathrm{V}-\mathrm{Y}
$$

if we bear in mind that the subject-verb word order in German is not compulsory but comes into being only by chance or, to be more precise, by information structure requirements. In itself, the subject is not more privileged 
to show up in the Vorfeld than any other constituent (cf. Rambow 1993: 2, contra Lenerz 1977:110). ${ }^{1}$

The two different constructions in English show different requirements as to information structure. They thus lead to two competing possibilities fo the analysis of Vorfeldbesetzung. One is that Vorfeldbesetzung works along the lines of English inversion. Inversion seems to be governed by Centering Theory (as outlined by Grosz, Joshi \& Weinstein 1995; Prince 1998; Walker, Joshi \& Prince 1998b). According to Centering Theory, referential expressions in an utterance are ranked in a list of forward-looking-centers $\left(=C_{f}\right)$. The ranking is done according to preferably non-pragmatic factors such as syntactic function and theta-roles. The highest ranked forward-looking center is called the preferred center $\left(\mathrm{C}_{\mathrm{p}}\right)$. Each sentence, furthermore, has a backward-looking center $\left(=\mathrm{C}_{\mathrm{b}}\right)$, which is the entity which links the utterance back to the previous discourse (i.e. which is coreferential with some entity in the previous discourse). Another, less technical term for this would be 'topic', on one definition of this term. The $\mathrm{C}_{\mathrm{p}}$ of an utterance is the entity which has the highest probability of be coreferential with the $\mathrm{C}_{b}$ of the following utterance. In a highly coherent discourse the $\mathrm{C}_{\mathrm{b}}$ of an utterance is coreferential with the $\mathrm{C}_{\mathrm{p}}$ of the preceding utterance.

Consider now the proposal made by Birner (1998) for English inversion as a simple starting hypothesis (cf. (1) from Birner 1998: 315): In inverted English sentences the preposed element always contains the $C_{b}$.

(1) Tich made tea in a blackened billy and McPherson filled a telescopic cup he took from a pocket. Seated on a form, he helped himself to sugar [...]. [Seated opposite him] was Tich, waiting for Gossip, wondering, hoping.

Since English inversion seems in some ways comparable to German Vorfeldbesetzung, it would not be surprising if the same were true for the German Vorfeld, viz. that it is the backward-looking center that is moved to Spec,CP.

The assumption that the Vorfeld contains the $\mathrm{C}_{\mathrm{b}}$ of the sentence is very much in line with the traditional assumption that the Vorfeld in German is the prototypical position for the 'topic' of the sentence (in general see Gundel

\footnotetext{
${ }^{1}$ Lenerz (1977: 110) is implicitly assuming that the normal position of the subject is the Vorfeld when he defines topicalization as a process of which the following is true: „Dabei wird das SU[bjekt] von dieser Position [i.e. the Vorfeld] verdrängt". But this conception is probably mostly due to the fact that on the version of Generative Grammar which was in use in the 1970s, the importance of functional categories such as IP and CP and the consequent position of the base generation of the subject was not fully recognized, and the subject, indeed, was thought to be the left sister of the whole verbal phrase, i.e. the rest of the sentence. So Lenerz and I disagree here only because we have different stages of the model as background.
} 
1985: 94; for German especially, see Reis 2000). A possible definition of topic is that it is the entity, already evoked in the previous discourse, which the sentence is about (Gundel 1985: 85). A further, more precise definition of 'topic' is the element that takes care that the proposition is represented as happening rather than as pure, timeless fact - in other words, anchors it into the linguistic and extralinguistic context (Reis 2000). The definition of $\mathrm{C}_{\mathrm{b}}$, as given in Grosz, Joshi \& Weinstein 1995 is not much more than the formalized version of this.

The second possibility for Vorfeldbesetzung is that it works along the lines of English topicalization (understood as in Prince 1999). In this case Centering Theory would not determine which elements are moved to the Vorfeld, but rather other processes: The topicalized element stands in a salient partiallyordered set relation to some entity evoked in the discourse. I do not want to go into the technical details of partially ordered sets (or 'posets' for short), but rather the reader refer to Hirschberg (1985:122) and Prince $(1999: 8)$ for this. For the moment it is sufficient to give the definition: A partially ordered set is a set whose members are in either a reflexive, transitive and antisymmetric relationship or in an irreflexive, transitive and asymmetric relationship. It is sufficient for the purposes of this paper to informally state that a poset relationship exists if there is a list of entities, explicitly or implicitly, and the topicalized element is part of that list, as in $(2 \mathrm{a}, \mathrm{b})$; is in contrast to some entity already evoked, as in (2c); or resumes a whole set already evoked, as in (2d).

(2) a. 'We've got Earl Grey, Ceylon, Lemon Ginger, Raspberry, Rose hip. Which'd you like?' - 'Earl Grey I'd like.'

b. Thanks to all who answered my note asking about gloves. I didn't look at this bb for several days and was astounded that there were 11 answers. Some I missed, darn.

(from Prince 1999: 1)

c. The necklace she got from a friend. The ring she bought for herself.

d. 'And who you invited for this spontaneous orgy, you chump?''Well, there's Charlie and Al and Liz and Pat and Tom and Shermy and Rick and John and Mary and Bill. All these guys you'll have to order pizza for, I'm afraid.'

Note that it is decidedly not the $\mathrm{C}_{\mathrm{b}}$ in the usual sense that comes into the Vorfeld on this view (cf. Prince 1999). So we end up with two diametrically opposed predictions about Vorfeldbesetzung in German.

In this article I want to examine whether either of these two predictions turns out to be true for German - in particular, whether Centering Theory can be used as a means to determine the constituent which is to be moved to Spec, CP, or not, and if not, what other factors play a role, so that looking for them might give the researcher a higher level of accuracy. It will turn out that 
both predictions come out true under certain circumstances, but that they do not represent the whole picture. To test the assumptions I used a corpus consisting of transcripts of radio broadcasts (only read-loud manuscripts), articles and readers' letters from the Stuttgarter Zeitung, selections from two handbooks on literature, and works by Friedrich Dürrenmatt and Günther Grass. I decided to take texts from a number of different stylistic levels; to confine myself to e.g. newspaper discourse would have distorted the results since in newspaper discourse presumably other factors (e.g. catching the attention of the reader) play a role whose importance it is not possible for me to estimate. A more precise listing of texts used is given at the end of this paper.

I am using the following fonts in my examples to mark several possible discourse-relevant properties of constituents:

bold:

$\mathrm{C}_{\mathrm{b}}(\mathrm{Un})$

underlined:

$\mathrm{C}_{\mathrm{f}}(\mathrm{Un}-1)$ coreferent with $\mathrm{C}_{\mathrm{b}}(\mathrm{Un})$

bold italic:

P- kontrast

bold italic double underlined: $\quad$ scene-setting / brand-new

\section{Findings}

\subsection{Centering Theory}

An analysis of sentences in the corpus reveals that the prediction that it is preferably the $\mathrm{C}_{\mathrm{b}}$ that occurs in the Vorfeld does not always obtain. It is true that the $\mathrm{C}_{\mathrm{b}}$ is often in the Vorfeld (3), but often it is not.

(3) Verteidigungsminister Peter Struck (SPD) hat gestern sein

Sparprogramm bekannt gegeben. Er sieht darin auch einen Schritt zur

Reform der Bundeswehr.

'Minister of Defence Peter Struck (SPD) proposed his program for cutting expenses yesterday. He sees it also as a step towards a reform of the Federal Army.' (StZ 1,1-2)

The performance is improved if one makes certain additions to Centering Theory proper and allows for NPs which are embedded in other structures as centers ((4a)); counts concepts rather than lexical items ((4b)), which includes also easily inferable sister-concepts $((4 \mathrm{c}))$; also allows the inclusion of whole situations as possible $\mathrm{C}_{\mathrm{f}} \mathrm{s}((4 \mathrm{~d}))$, even when they are only inferable $((4 \mathrm{e}))$; allows for certain adverbial referential expressions ((4f)), even in ellipsis $((4 \mathrm{e}))$; and permits centers from not the immediately preceding sentence, but the sentence before that $((4 \mathrm{~g}))$. Let us go into these additional conditions in 
more detail; it will turn out that each condition can be maintained without interfering with the core of Centering Theory.

(4) a. Gips sei billig und binde schnell ab, sagen die Experten. [Ein rund drei Tonnen schwerer Block in Gips mit dem mittleren Körperabschnitt] steht zurzeit noch auf dem Bauhof in Eislingen. 'Plaster is cheap and dries out fast, the experts say. A block of plaster, weighing about three tons, containing the middle part of the body still stands in the builder's yard in Eislingen.' (StZ 3,3031)

b. Die Landesverteidigung solle künftig nicht mehr primäre Aufgabe der Bundeswehr sein. Die Streitkräfte sollten vielmehr im UNAuftrag, überall auf der Welt' einen Beitrag zur internationalen Sicherheit leisten.

'The defense of the country shall in the future no longer be the primary task of the Federal Army. The armed forces shall instead contribute to international security, under the commission of the U.N., everywhere in the world.' (StZ 1, 8-9)

c. Außerdem arbeiten sie unter einem ziemlichen Zeitdruck: Bereits im kommenden Jahr soll ihr derzeitiges Projekt beendet sein [...]. 'Furthermore they work under quite some time pressure: next year their recent project is already supposed be finished.' (StZ 3, 7-8)

d. Die Bundeswehr, die im Grundsatz bisher allein der Landesverteidigung verpflichtet war, soll nach Strucks Vorstellung zu einer Streitkraft werden, deren primäre Aufgabe Konfliktverhütung und Krisenbewältigung irgendwo auf der Welt ist, weil auch das der Verteidigung dient. Diese Verschiebung der Prioritäten ist zweifellos notwendig. 'The Federal Army, which was in principle up to now only committed to homeland defence, should become, according to Struck's ideas, an armed force whose primary task is prevention and management of conflicts anywhere on earth, as this also contributes to defense. This shift of priorities is certainly necessary.' (StZ 2, 21-22) 
e. Jene episch-lyrisch getönten Kantilenen lebten über Generationen hinweg ausschließlich in mündlicher Tradierung fort und wurden [...] zur Stärkung des Kampfeswillens vor den Schlachten rezitiert. Als Beleg <sc. dafür> ließen sich Williams von Malmesbury Gesta Regum Anglorum anführen [...].

'Those canzonas in an epic-lyric style existed over generations only in oral tradition and were [...] recited before battles in order to strengthen the determination to fight. As an instance $<$ sc. of that $>$ one could cite William of Malmesbury's Gesta Regum Anglorum.' (HL 2, 7-8)

f. Die neunzig Tornado, die Struck aus dem Verkehr ziehen will, sollen zwischen 2005 und 2012 außer Dienst gehen. Erst dann kommt es zur Kostenentlastung.

'The 90 Tornados (= fighter jets) that Struck wants to withdraw should end service between 2005 and 2012. Only then will there be some relief of expenses.' (StZ 2, 10-11)

g. Ein Beispiel bietet das oben zitierte Absagelied Friedrich von Hausens $[\ldots]$ in dem die Techniken der Reimresponsion und isolierung (Waisen) die Strophe in die Spannung zweier Zeilenblöcke fügen. Hier scheint es sich um eine eigenständige Erfindung des Autors in romanisierendem Stil zu handeln. Andere Strophenformen deutscher Sänger, vor allem des Westens, sind direkt Kontrafakturen romanischer Texte.

'An example is the refusal song quoted above of Friedrich von Hausen in which the techniques of rhyme correspondence and rhyme isolation (orphans) press the stanza into a tension between two blocks of verses. This seems to be an original invention of the author in Romanizing style. Other forms of stanzas of German poets, especially of the west, are direct contrafacta of Romance texts.' (HL 1, 10-12)

The first condition, that NPs which are embedded in other structures can function as centers, does not need a justification; neither Grosz, Joshi \& Weinstein (1995) nor Walker, Joshi \& Prince (1998b) commit themselves to which grade of embedding is allowed. The same goes for the second and the third conditions - that is, that we should think of centers as concepts rather than lexical items, and that different worded concepts and easily inferable sister-concepts can count as centers as well (see Birner 1998: 318); and that whole situations should be included as possible $\mathrm{C}_{\mathrm{f}} \mathrm{s}$, even when they are only inferable. The second condition poses no problem since discourse models are representations in the minds of the discourse participants and it is to be expected that the entities in the discourse model are represented as one would 
expect from mental processes, i.e. as concepts rather than as surface word forms. Especially in written discourse the limitations of a surface-oriented mental representation are obvious, as there the stylistic pressure for variation makes it rather rare that the same entity is referred to by the same word twice in rapid succession. And the third condition follows indirectly from the claim made in Walker, Joshi \& Prince 1998 b that a $C_{b}$ need not be explicit but can also be only inferable. The distinction in Grosz, Joshi \& Weinstein 1995 between realized and directly realized centers takes this into account. We can say that centers in German do not need to be directly realized.

It is slightly more difficult to reconcile the fourth and fifth conditions with classical Centering Theory, but it is not impossible. The fourth is perhaps easier than the fifth. The fourth condition, i.e. that also certain referential adverbials should count as centers, even when they are overtly in ellipsis, seems to need justification if one takes Centering Theory to be a theory that deals only with noun phrases. This is not the case. Grosz, Joshi \& Weinstein (1995) never say that it is only NPs which are relevant, but rather imply that it is any referential expression (which are mostly NPs, though); and Walker, Joshi \& Prince (1998b) do not commit themselves either to any claim about the types of semantic entities which can be centers. Since we are in the field of concepts, which probably are category-neutral, a restriction which makes reference to NPs would be rather odd. The only condition which a constituent must fulfil in order to be a possible candidate for Centering Theory is that it is a referential expression. That surely goes for referential adverbs like dann, 'then', hier 'here', damit 'with/by that', dafür 'for that', and davon 'of that'. Even if one wanted to confine Centering to noun phrases, it is easy to see that adverbs of the sort listed above are functioning like prepositional phrases with a referential expression as complement of $P$ and can easily be replaced by such prepositional phrases. In many cases they are actually PPs and still recognizable as such. So they are embedded NPs in some ways, which would make this condition only a subcase of the first condition.

The fifth condition finally appears to be in sharp contradiction to the locality condition as it is stated in Grosz, Joshi \& Weinstein (1995). But one has to allow for that, in order to account for the phenomenon of insertions. Insertions are not part of the general discourse but addenda to one or the other entity evoked in the utterance immediately preceding the insertion. They thus represent little embedded discourse segments.

Thus it seems that the definition of locality, as it appears in Grosz, Joshi \& Weinstein 1995, has to be extended: In principle, the $C_{b}\left(U_{n}\right)$ has to be taken from the set of $C_{f}\left(U_{n-1}\right)$. Under certain circumstances however, namely if $U_{n-1}$ forms an embedded, self-contained sub-discourse with $U_{n-2}$, the $C_{b}\left(U_{n}\right)$ can be taken from the set of $C_{f}\left(U_{n-2}\right)$ (cf. Birner 1998: 320). This is very much in line with Walker's (2000) observation, starting from work by Grosz \& Sidner (1986), that discourse segments can be both linearly recent and hierarchically 
recent. The case of insertion is an example of hierarchical recency: the utterances before and after the insertion are on the same hierarchical level and thus recent on that level. Since insertion cases are rather common, we can conclude that, at least in German, hierarchical recency is a sufficient condition for locality.

It is perhaps interesting to note that, although $\mathrm{C}_{b}\left(\mathrm{U}_{\mathrm{n}}\right) \mathrm{s}$ which are coreferential with one member of the set of $\mathrm{C}_{\mathrm{f}}\left(\mathrm{U}_{\mathrm{n}-2}\right)$ are undoubtedly functioning as centers, they behave quite differently from linearly recent centers in that they are in most cases not in the Vorfeld, whereas for linearly recent centers there is clearly a tendency to appear in the Vorfeld if nothing hinders them, as suggested in (5).

(5) Mit einem Haushalt von 24,4 Milliarden Euro [...] hat die Bundeswehr laut Struck eine ,solide finanzielle Grundlage“. Enthalten seien in diesem Etat 1,15 Milliarden Euro für Auslandseinsätze und für den Kampf gegen den internationalen Terrorismus. [Die Opposition] $]_{v f}$ übte [gestern Kritik am Verteidigungsminister $]_{\mathrm{mf}}$

'With a budget of 24.4 Billion euros, the army has a sound financial basis, according to Struck. Included in this budget are 1.15 Billion euros for action abroad and the battle against international terrorism. The opposition criticized the defense minister yesterday.' (StZ 1,18-20)

It should be noted that, although it is very often the subject which is in Spec, CP, in the corpus there are numerous cases where the $\mathrm{C}_{\mathrm{b}}$ is in Spec,CP position, but is not the subject (contra Rambow 1993: 8). The effect that the subject ends up quite often in Spec, $\mathrm{CP}$ is only a reflex of the fact that the subject in many cases simply is the $\mathrm{C}_{\mathrm{b}}$ (see table 3 ) - what one would expect from sentences between which there is a continuation transition (cf. Grosz, Joshi \& Weinstein 1995: 10; Walker, Joshi \& Prince 1998b: 6), if the relative ranking of $\mathrm{Cfs}$ in German is as it is in most other more or less related languages and involves a ranking Subject $>>$ all others (for English, see, e.g., Walker, Joshi \& Prince 1998b:7).

But even so Centering Theory does not account for a large number of cases. In toto it is only 319 out of 622 sentences $(=51.29 \%)$ which have the $C_{b}$ in the Vorfeld. The exact numbers can be taken from table 1.

Table 1: Proportion of backward looking centers in the Vorfeld

\begin{tabular}{|l|l|l|l|l|l|l|l|l|}
\hline & $G r T$ & $D \ddot{u} R$ & $H L+D L M$ & $S t Z$ & $A u$ & $E$ & $R$ & total \\
\hline \# sent. & 68 & 61 & 68 & 188 & 62 & 85 & 90 & $\mathbf{6 2 2}$ \\
\hline $\begin{array}{l}\text { \# } C_{b} \text { in } \\
V F\end{array}$ & 22 & 35 & 43 & 90 & 38 & 27 & 64 & $\mathbf{3 1 9}$ \\
\hline$\%$ & $\mathbf{3 2 . 3 5}$ & $\mathbf{5 7 . 3 7}$ & $\mathbf{6 3 . 2 4}$ & $\mathbf{4 7 . 8 7}$ & $\mathbf{6 1 . 2 9}$ & $\mathbf{3 1 . 7 6}$ & $\mathbf{7 1 . 1 1}$ & $\mathbf{5 1 . 2 9}$ \\
\hline
\end{tabular}


Table 2: Proportion of Subjects among backward-looking centers in the Vorfeld

\begin{tabular}{|l|l|l|l|l|l|l|l|l|}
\hline & GrT & DüR & $H L+D L M$ & StZ & $A u$ & $E$ & $R$ & total \\
\hline $\begin{array}{l}\# C_{b} \text { in } \\
\text { VF }\end{array}$ & 22 & 35 & 43 & 90 & 38 & 27 & 64 & $\mathbf{3 1 9}$ \\
\hline$\#$ Subj. & 17 & 34 & 32 & 53 & 30 & 19 & 34 & $\mathbf{2 1 9}$ \\
\hline$\%$ & $\mathbf{7 7 . 2 7}$ & $\mathbf{9 7 . 1 4}$ & $\mathbf{7 4 . 4 2}$ & $\mathbf{5 8 . 8 9}$ & $\mathbf{7 8 . 9 5}$ & $\mathbf{7 0 . 3 7}$ & $\mathbf{5 3 . 1 3}$ & $\mathbf{6 8 . 6 5}$ \\
\hline
\end{tabular}

We note that what most readily have the $\mathrm{C}_{\mathrm{b}}$ in the Vorfeld are radio manuscripts, closely followed by academic discourse, whether written purely for reading or for oral presentation. The smallest portion of centers in the Vorfeld are found in letters to the editor and Grass's 'Treffen in Telgte'; that the low percentage of the latter has nothing to do with literary style in general is obvious if one compares it to the percentage in Dürrenmatt's 'Der Richter und sein Henker'.

For the remaining half of the sentences one obviously needs other theories.

\subsection{Topicalization}

Almost all remaining cases, i.e. sentences where the $\mathrm{C}_{\mathrm{b}}$ is not in the Vorfeld, can be characterized in terms of three notions: namely, 'kontrast', brand-new information or scene-setting. Since these notions will turn out to be more crucial to Vorfeld-filling than Centering, we will dwell on them a bit here.

Kontrast is used in the sense of Vallduví \& Vilkuna (1998): a semantic operation that constructs a membership set out of the entity over which it operates together with comparable entities.

kontrast (a) $\rightarrow \mathrm{M}=\{\ldots, \mathrm{a}, \ldots\}$

Note that this notion shares only the word (or better, phonetic form) with 'contrast' in the popular sense. The construction of a membership set $M$ as described above does not necessarily imply that the entity stands in contrast with the other members in the set. Contrast in the popular sense comes into the play if we try to combine the notion of kontrast (in Vallduví \& Vilkuna's sense) with the idea of posets (Prince 1999). A poset relationship can be seen as a special case of kontrast in that the additional condition holds that at least one other member of the set generated by kontrast must be evoked in the previous discourse, and the rules of the membership are determined by the notion of the poset relation.

So the poset-case of kontrast (in the following short P-kontrast) can be described as follows:

$$
\text { P-kontrast (a) } \rightarrow \mathrm{M}=\{\ldots, \mathrm{a}, \mathrm{b}, \ldots\} ; \mathrm{a} \in \mathrm{U}_{\mathrm{n}} ; \mathrm{b} \in \mathrm{U}_{\mathrm{n}-\mathrm{m}} ; \mathrm{m}<\mathrm{n}
$$

There is a strong tendency to put the element which is kontrastive in the Vorfeld. In most cases there is also a poset relationship with something from 
the previous discourse. This is thus completely in line with topicalization in English (Whitton 2004). What is different from topicalization, however, is that a stronger condition holds: in almost all cases of P-kontrast the member b is taken from the directly preceding utterance. So for German the following holds:

$$
\text { P-kontrast (a) } \rightarrow \mathrm{M}=\{\ldots, \mathrm{a}, \mathrm{b}, \ldots\} ; \mathrm{a} \in \mathrm{U}_{\mathrm{n}} ; \mathrm{b} \in \mathrm{U}_{\mathrm{n}-1}
$$

But note that such P-kontrast cases still do not need to express contrast in the popular sense; usually they do not. That means that most of the P-kontrast cases are not focalized. ${ }^{2}$

In the case of P-kontrast the set $M$ can be used exhaustively, as in (6a), or non-exhaustively, as in (6b).

\footnotetext{
${ }^{2}$ Contrast in the everyday sense is, however, subsumed under P-kontrast; a definition of contrast in the ordinary sense in that framework could be: 'elements standing in (exhaustive) P-kontrast relationships to other elements which in addition are focalized'. This brings normal contrast in terms of intonation closer to brand-new elements. Rochemont \& Culicover (1990: 21), following Rochemont (1986: 52), distinguish between Presentational Focus and Contrastive Focus. Presentational focus is assigned to phrases which are not construable from the context, so are essentially discourse-new; and it serves to introduce an individual into the discourse (Culicover \& Rochemont 1983: 155; Rochemont 1986: 52). Contrastive Focus is assigned to phrases which are not discourse-new, but construable from the context, and for which it is true that the hearer believes that some element in the speaker's utterance is not true, but some other entity comparable to the doubtful element is true (Culicover \& Rochemont 1983: 152f.). These authors note (1990:21) - which is important - that these two kinds of focus form a syntactically uniform notion, although they are interpretatively distinct. In fact, in earlier work they show that this distinction is purely with respect to the interpretation of the foci and has no impact on the structure; that is to say, there is one structural notion of focus, which can be interpreted in two different ways, namely presentational and contrastive (Culicover \& Rochemont 1983:151). They demonstrate this structural identity with the similar behaviour of these kinds of focus with respect questionability and accent. Roughly speaking, in their view, the focus of a sentence is the phrase which has a lexical item in it (usually the rightmost one) that receives an accent. In question-answer pairs the definition is even simpler: The focus of the answer is the part which corresponds to the wh-word in the question. The point, that the two different interpretations of focus do not correspond to separate syntactic concepts but are treated as one phenomenon for syntax, is important for the argument further developed in their book, which is essentially a rundown of English sentence-types which mark focus by non-standard word-order. It might be noted in passing that it has already been observed for German that focus elements tend to appear either as far to the right as possible - or, quite contrary to that, in the Vorfeld (Reis 1987:169).
} 
(6) a. Deshalb erreichten Moscherosch und Schneuber, die von Straßburg her die Reise gemacht hatten, ausgeraubt (bis auf ihre den Wegelageren nichtsnutzen Manuskripttaschen) das abgesprochene Ziel: Moscherosch lachend und um eine Satire reicher; Schneuber jammernd und schon die Schrecken des Rückweges vor Augen. 'Therefore Moscherosch and Schneuber, who made their travel from Strasbourg, reached the destination agreed upon, mugged (save for their bags of manuscripts, not useful for the robbers): Moscherosch laughing and with one satire more on his account, Schneuber moaning and already afraid of the terrors of the travel back.'

$\mathrm{M}=\{$ Moscherosch, Schneuber $\}$

(GrT 1, 11-13)

b. So gehen die Experten davon aus, dass am Grund des Meeres damals eine leichte Strömung vorgeherrscht haben muß. Hunderte versteinerte Tintenfische wurden in einer entsprechenden Anordnung gefunden. Die Kadaver der Saurier waren gegen abgesunkene Baumstämme geschwemmt worden [...].

'Thus the experts suppose that on the bottom of the sea there was then a light current. Hundreds of fossilized squids were found in a suggestive formation. The corpses of the $<$ plesio $>$ saurs have been washed against sunk trees.' (StZ 3, 37-39)

$\mathrm{M}=\{\ldots$, Tintenfische, Saurier,... $\}$ (= animals which can end up on the bottom of Jurassic lagoons)

It can be seen that the notion of P-kontrast need not exclude the other, less important requirement that the $\mathrm{C}_{\mathrm{b}}$ is in the Vorfeld, as shown in (7).

(7) a. Gestern wird sein, was morgen gewesen ist. Unsere Geschichten von heute müssen sich nicht jetzt zugetragen haben. Diese fing vor mehr als dreihundert Jahren an. Andere Geschichten auch. 'Yesterday will be what tomorrow has been. Our stories from today do not need to have happened now. This one began over three hundred years ago. Other stories too.' (GrT 1, 1-4) 
b. Er erlaubt den militärischen Führern nicht mehr, sich von Jahr zu Jahr über das wahre Ausmaß der öffentlichen Finanznot hinwegzutäuschen [...]. Anders als sein Vorgänger Rudolf

Scharping, der auf eine geradezu märchenhafte Einnahmevermehrung baute, zwingt Struck die Generäle, die Augen zu öffnen.

'He no longer permits the military leaders to fool themselves about the real extent of the financial tightness of the state. Differently from his predecessor Rudolf Scharping, who relied on a nearly miraculous increase in earnings, Struck forces the generals to see reality.' (StZ 2, 3-4)

In sentences like (7), there are two good reasons for the element which is in the Vorfeld to be in the Vorfeld: firstly, because the phrases in the Vorfeld contain the $\mathrm{C}_{\mathrm{b}}$; and secondly, because the phrases in the Vorfeld are in Pkontrast. But what happens if there is a conflict between the requirements of Centering Theory (i.e. that the $\mathrm{C}_{\mathrm{b}}$ be in the Vorfeld) and of P-kontrast (i.e. that the P-kontrastive element be in the Vorfeld)? In my samples all of the conflicting cases suggest that P-kontrast overrides Centering if there is a conflict, as in (8). Note that a different order would indeed sound slightly deviant, as shown in (9).

(8) Ihre heimischen Zirkel faßten zu eng. Kein langwieriges Geschäft, keine kurzweilige Liebe konnte sie binden.

'Their circles at home were too narrow. No long-living business, no entertaining love could bind them.' (GrT 1,37-38)

(9) Ihre heimischen Zirkel faßten zu eng. \#Sie konnte kein langwieriges

Geschäft, keine kurzweilige Liebe binden.

$\mathrm{M}=\{$ Geschäft, Liebe $\}$

But it should be noted that even here there is still a tendency to place the $\mathrm{C}_{\mathrm{b}}$ as close to the front as possible, i.e. into the first position of the Mittelfeld (cf. Lenerz 1977:106ff.; Rambow 1993: 5). In case the $C_{b}$ is the subject, this position even seems to be obligatory (cf. also Lenerz 1977: 97ff.; Rambow 1993: 5), since there were no examples in my samples where the $C_{b}$ is the subject and occurs somewhere other than in the Vorfeld or the first position of the Mittelfeld. The relative preference of the subject to occur as far to the left as possible has been noticed as 'normal word order' insofar as sentences with the subject as the first spelt-out argument allow the highest number of potential foci and thus can occur in more contexts than sentences where the subject is preceded by some other argument (Höhle 1982: 122ff.). 
(10) Der Grabungsleiter Reinhard Rademacher und seine beiden Kollegen Philipe Havlik und Hendrik Stöhr nehmen noch schnell einige Koffeinschübe, bevor sie sich ans Werk machen. Etwas Aufmunterung können sie gut gebrauchen.

'The leader of the excavation R.R and his two colleagues P.H. and H.S. take quickly a few shots of caffeine. A bit of bucking up they can use.' (StZ 3, 5-6)

This is not at all surprising. Centers are, according to the claims of Centering Theory, pretty much what in other frameworks is described as 'topic' (Walker, Joshi \& Prince 1998b: 3), or 'theme' in Prague School terminology (cf. Lenerz 1977: 9ff.). Topics/themes, however, are known to favour positions rather far to the left, e.g. in a left periphery relative to the base-generated order of the core constituents of the verbal phrase (i.e. the verbal head and its arguments; see Lenerz 1977:15ff.; Jacobs 2001:644). Lenerz demonstrates throughout his 1977 study that one of the main factors governing scrambling in the Mittelfeld is pragmatic: namely, the establishment of a theme-rheme structure (cf. also Reis 1987:150f.). And the special status of the subject in that respect is also not surprising. The unmarked position of the subject is in the first Mittelfeld position (Lenerz 1977:97ff.), which is, in fact, also the base-generated position (Spec,VP; unmarked strings in the Mittelfeld are to be thought of as equivalent to the base-generated strings; cf. Reis 1987: 154 contra Lenerz 1977:30), so it suffices, in cases where the topic is the subject, to leave it there. If the topic is not the subject, however, or if the topic is the subject and nothing prevents it from moving further left, movement of the topic to Spec,CP (a movement to the left periphery in Jacobs's sense) is clearly favoured. Lenerz makes pretty much the same observation when he notes that the leftmost constituent in the Mittelfeld is either the theme in a more general sense, or else what he calls the 'Mitteilungszentrum', which usually is the subject but in certain cases, with psych-verbs, passives etc., typically not (Lenerz 1977:106ff.). Mitteilungszentrum is defined as the entity which participates most closely in the proposition of the sentence (Lenerz 1977:108); in the case of verbs which assign an agent-role to their subject, the Mitteilungszentrum must be the subject and inside the Mittelfeld no constituent can be moved in front of it (Lenerz 1977:119; Reis 1987:150).

\subsection{Other Processes}

Besides P-kontrast there are two other properties which a constituent can have in order to be eligible for Vorfeld positioning: brand-new information and scene-setting.

Scene-setting is rather self-explanatory. Brand-new information is taken, in the sense of Prince (1981), as information which is both discourse-new and 
hearer-new, or also in the sense of Rochemont (1986: 52) as information which is not construable from the context.

A problem with this finding, at first glance, seems to be that it disturbs the neatness of the cases of Vorfeldbesetzung which were comparable to topicalization and inversion. Without this other process we could say that in the German Vorfeld two pragmatically different constructions are merged which in a language without a strong verb-second constraint, such as English, are syntactically distinct from each other. But on closer inspection, we see that English also offers a construction for the case of brand-new elements, which shares with both topicalization and inversion the properties that it involves non-canonical word order and that a constituent with certain well-defined properties is fronted to the topmost position in the clause. The construction to which I am referring is left-dislocation.

Left-dislocation is distinct from topicalization in that the movement of the fronted element does not leave a gap in the clause; rather a coindexed pronoun, an overt trace, so to speak, is left behind (Prince 1997). The contrast can be made clear from example (11) (after Prince 1997: 125 (9e); 129 (12; $14))$ ), where (11a) is topicalization and (11b) is left-dislocation. There are different discourse issues involved in the choice of topicalization and leftdislocation (see Prince 1997); (11a) is felicitous in contexts where (11b) is not and vice versa, but I can leave that aside for the moment.

(11) a. She had an idea for a project. She would take three groups of mice. $[\text { One }]_{i}$ she'll feed $[\mathbf{e}]_{i}$ mouse chow. [The second $]_{i}$ she'll feed $[\mathbf{e}]_{i}$ veggies, and [the third $]_{\mathrm{i}}$ she'll feed $[\mathbf{e}]_{\mathrm{i}}$ junk food.

b. She had an idea for a project. She would take three groups of mice. $[\text { One }]_{\mathrm{i}}$ she'll feed [them $]_{\mathrm{i}}$ mouse chow. [The second $]_{\mathrm{i}}$ she'll feed $[\text { them }]_{\mathrm{i}}$ veggies, and $[\text { the third }]_{\mathrm{i}}$ she'll feed $[\text { them }]_{\mathrm{i}}$ junk food.

Left-dislocation can serve three distinct discourse functions, two of which are rather similar to or related to topicalization (Prince 1997). One function, which has nothing to do with topicalization - so-called 'simplifying left-dislocation' - is the function which is of interest in this context. Prince (1997: 124) defines this discourse function roughly as follows: When discourse-new information is introduced into a discourse and it is located in a phrase generated in a syntactic position disfavoured for new information, this phrase can be moved into clause-initial position, thus creating a separate processing unit for the phrase containing new information. An example of a simplifying left-dislocation can be seen in (12) (from Prince 1997: 121, (3)):

(12) It's supposed to be such a great deal. [The guy] $]_{i}$, when he came over and asked me if I wanted a route, $[\text { he }]_{\mathrm{i}}$ made it sound so great.

Simplifying left-dislocation in English and the remaining cases of Vorfeldbesetzung in German have something important in common: there is a 
brand-new entity involved, and it is moved to a position at the top of the clause. Whereas in English this occurs in a construction with non-canonical word order, in German this movement can be taken as one flavour of Vorfeldbesetzung among others, a process which is compulsory anyway. This also goes for the other two constructions which were mentioned in this paper.

The only problem is that German has left-dislocation too, as shown in (13), which distinct from Vorfeldbesetzung; and it is not entirely clear under what circumstances left-dislocation is used in German. Altmann 1981, the standard account of left-dislocation and similar constructions in German, speaks noncommittally of 'thematicity-marking' („LV-Strukturen dienen primär der Thematisierung", 1981: 48), and treats left-dislocation on a par with Vorfeldbesetzung (he speaks of double Vorfeldbesetzung, assuming (wrongly; see (13b)) that left-dislocation automatically involves movement of the coindexed pronoun to the Vorfeld (1981: 162). Jacobs (2001) counts left dislocation (cases like (13a); taken from Altmann 1981: 147) and hanging topic left dislocation (cases like (13b)) under his rundown of constructions explicitly marking a topic-comment structure. I will leave this issue for further research, especially since it is not of crucial relevance in this context. The important issue is this one: in situations where English would employ (simplifying) left-dislocation, German can use the multi-functional means of Vorfeldbesetzung.

(13) a. [Dieser Raum $]_{i},[\text { der }]_{i}$ macht mich wirklich depressiv. 'This room, it really depresses me.'

b. [Der Typ da $]_{i}$, ich würd' $[\text { dem }]_{i}$ keine zwei Meter über den Weg trauen.

'That guy, I would not trust him a bit.'

The data might suggest that scene-setting can be seen as a subcase of brandnew information (see the examples in (14)) in that the information in scenesetting elements is as a rule discourse-new, usually also hearer-new in some respect. Then one could assume that it is by virtue of these elements being brand-new rather than setting the scene that they are moved preferably to the Vorfeld. However, let us abandon this assumption for a moment and think more about the nature of scene-setting.

Rochemont (1986: 55) points out that scene-setting elements are, quite in contrast to brand-new (and thereby Presentational Focus elements), always indirectly c-construable - that is, not noteworthy for the recipient, even if it is new information, since it serves only as a scene-setting device. Molnár (1991:183) notes that in languages which have a pre-specified position for topics this position is often filled with temporal and local specifications. And Jacobs (2001:649) points out that adverbials of spatial or temporal position i.e. roughly what I have called scene-setting - share important properties with 
archetypal topics in that they fulfil two semantic conditions of topics: information separation and the specification of a semantic variable of the verb, namely the situation variable. ${ }^{3}$ This view is supported by the fact that in languages like Hungarian, in which the topic position is strictly sentenceinitial (Molnár 1991: 135ff., 165), temporal and local adverbials can nevertheless occur in exactly that position (Molnár 1991:184; cf. Jacobs 2001: 649).

We have seen that the Vorfeld in German sentences can be used as a topic position if there is no kontrastive (and thus focus) element which competes with it. If scene-setting elements are topics in some sense (and in German they share properties with other proper topics, e.g. they can be left-dislocated; Jacobs 2001: 649), it is not surprising that they can compete for Vorfeld position as well.

But what about our idea that many English constructions involving noncanonical word-order correspond to just one construction, viz. Vorfeldbesetzung in German? Should we not expect some English construction to cover that sub-type of German Vorfeldbesetzung?

Yes, we should, and indeed there is an English construction which makes use of non-canonical word order which is confined to the introduction of scene-setting elements, namely Directional and Locative Inversion (see Rochemont \& Culicover 1990: 69ff.).

A closer look at this construction, however, reveals that at least in English there are crucial differences to e.g. the construction which marks brand-new information, namely left-dislocation. One of the major differences is that Directional and Locative Inversion identifies the postverbal subject as focus (Rochemont \& Culicover 1990: 24ff., 69). It is consequently not the focus which is fronted in this case. This is in sharp contrast to left-dislocation, which does not mark a phrase explicitly as focus. So perhaps it would be better to treat scene-setting as a fourth condition in its own right.

Both conditions under discussion, i.e. scene-setting and brand-new, as illustrated, respectively, in (14) and (15), override both centering ((14a), (15a)) and P-kontrast ((14b), (15b)). Again, a different word order would sound slightly deviant, as (16) shows, especially if Centers are involved, as in (16a,c).

A ranking of scene-setting and brand-new with respect to each other could not be extracted with certainty from the data and is hard to extract anyway, since it is often the case that scene-setting elements also offer brand-new

\footnotetext{
${ }^{3}$ It should be noted here that Jacobs's view of topic does not at all coincide with the notion of backward-looking center in Centering Theory, in that topics can either be new or belong to the background (2001:645), whereas backward-looking centers per definitionem cannot present new information and must be part of the background. Therefore a classification of scene-setting elements as brand-new entities would not be contradicted by that.
} 
information. It was obviously this fact which led me to treat these two conditions under one heading to begin with. There was only one case in which there were two discourse-new entities introduced into a sentence, one scenesetting, and one not. Here the scene-setting element was the one that was preferred for Vorfeld-movement, as shown in (17). But to conclude from this that scene-setting in general beats new information would be premature; I found at least one example in which the scene-setting element offered no new information and was not in the Vorfeld, outrun by a brand-new element which was moved to the Vorfeld, as shown in (18). The example comes from an article about Daniel Libeskind's proposal for the new World Trade Center, and in this context the date $9 / 11$ would be evoked anyway, but was explicitly mentioned several times in the article.

(14) a. Zwar den weitesten Weg [...] doch den sichersten [...] nahm Simon Dach, dessen Einladungen diesen Aufwand ausgelöst hatten. Schon im Vorjahr $[. .$.$] waren die vielen einladenden und den$ Treffpunkt beschreibenden Briefe geschrieben [...] worden. 'The farthest way, but the most secure Simon Dach took, whose invitations started this business. Already in the preceding year the many letters, inviting and describing the meeting point, had been written.'

(GrT 1, 21-22)

b. Nicht nur der fast vollständig erhaltene Schnittzahnsaurier ist eine Besonderheit. Aufeiner Fläche von sechzig Quadratmetern haben die Wissenschaftler die Skelette von mindestens sechs Fischsauriern, Ichthyosaurier genannt, entdeckt.

'Not only the themnodontosaur, preserved almost in its entirety, is something special. On an area of 60 square meters the scientists have discovered the skeletons of at least six fish-saurs, so-called ichthyosaurs.' $\mathrm{M}=\{$ Schnittzahnsaurier, 6 Ichthyosaurier $\}$

(15) a. Er mahnte aber auch, eine ernst gemeinte Überprüfung $<$ sc. der Wehrpflicht $>$ dürfe nicht von der Alternativlosigkeit der Wehrpflicht ausgehen. Mit einem Haushalt von 24,4 Mrd. Euro, der bis 2006 stabil bleiben soll, hat die Bundeswahr laut Struck eine ,solide finanzielle Grundlage'.

'He also warned that a serious reconsideration < of conscription> must not take the lack of alternatives to conscription as a starting point. With an budget of 24.4 billion euros that should remain stable until 2006, the federal army has a sound financial basis, according to Struck.' 
b. Diese sinnstiftende Zusammenfassung ist indessen nicht das Werk eines bewußt komponierenden einzelnen Künstlers, sondern vollzieht sich anonym im Volk. Joseph Bédier und Philipp August Becker versuchten demgegenüber (sc. the approach described in the last sentence), der modernen Konzeption des schöpferischen Individuums auch im Mittelalter zum Durchbruch zu verhelfen. 'This sense-creating composition is however not the work of a consciously composing individual artist but happens anonymously inside the population. Joseph Bédier and P.A. Becker tried instead to promote the modern concept of the creative individual also for the Middle Ages.'

(HL 2, 10-11)

(16) a. Zwar den weitesten Weg [...] doch den sichersten [...] nahm Simon Dach, dessen Einladungen diesen Aufwand ausgelöst hatten. \#Die vielen einladenden und den Treffpunkt beschreibenden Briefe waren schon im Vorjahr geschrieben worden.

b. Nicht nur der fast vollständig erhaltene Schnittzahnsaurier ist eine Besonderheit. \#Die Skelette von mindestens sechs Fischsauriern, Ichthyosaurier genannt, haben die Wissenschaftler aufeiner Fläche von sechzig Ouadratmetern entdeckt.

c. Er mahnte aber auch, eine ernst gemeinte Überprüfung $<$ sc. der Wehrpflicht $>$ dürfe nicht von der Alternativlosigkeit der Wehrpflicht ausgehen. \#Laut Struck hat die Bundeswehr $\underline{\underline{\text { mit }}}$ einem Haushalt von 24,4 Mrd. Euro, der bis 2006 stabil bleiben soll, eine ,solide finanzielle Grundlage'.

d. Diese sinnstiftende Zusammenfassung ist indessen nicht das Werk eines bewußt komponierenden einzelnen Künstlers, sondern vollzieht sich anonym im Volk. \#Demgegenüber versuchten Joseph Bédier und Philipp August Becker, der modernen Konzeption des schöpferischen Individuums auch im Mittelalter zum Durchbruch zu verhelfen.

(17) Eine eigene musikalische Grammatik, aufgrund derer wir über den weiteren Verlauf der Tonfolge Erwartungen aufbauen. Am MaxPlanck-Institut für Neuropsychologie in Leipzig ist der Musikwissenschaftler Stephan Kölsch auf diese musikalische Syntax gestoßen.

'An autonomous musical grammar, by which we build up expectations about the further development of the melody. At the MPI for neural psychology in Leipzig the musicologist Stephan Kölsch discovered this musical syntax.'

(R2 A6, 5-6) 
(18) Mehr als 100000 Jobs sind nach dem 11. September in Manhattan verloren gegangen.

'More than 100000 jobs have been lost after 9/11.'

(StZ 6, 19)

It is interesting to note that, whereas in the case of centering there is still a strong tendency to put the $\mathrm{C}_{\mathrm{b}}$ as far to the left as possible, in the case of Pkontrast this position seems not to be preferred, as suggested by (14b). This is not surprising, given the tendency of thematic or topic-elements to permeate as far to the left as possible - a tendency not shared by P-kontrastive elements, which are not necessarily thematic and sometimes can even be focalized.

\section{Conclusions}

The original aim of this paper was to investigate whether Centering Theory can make predictions about which constituent is moved to the Vorfeld in cases where the expression in the Vorfeld is referential. It seems from the data as if Centering Theory is in principle at work and tries to put the $\mathrm{C}_{\mathrm{b}}$ into the Vorfeld position, but can be overridden by other processes (cf. for a different conclusion Rambow 1993: 5). The most important process seems to be kontrast in the sense of Vallduví \& Vilkuna (1998); also important is the exposition of brand-new information (in the sense of Prince 1981) and scenesetting elements. Both scene-setting and brand-new information override Pkontrast for Vorfeld eligibility. Let me illustrate this with the diagram in (19). ${ }^{4}$

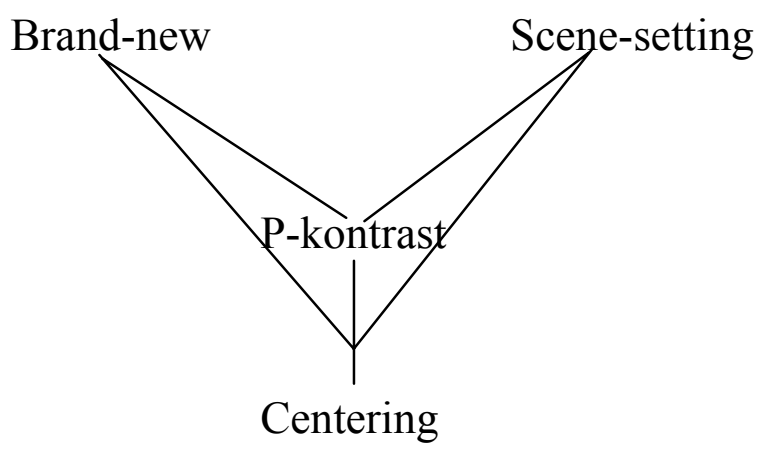

The Vorfeld position thus seems to be pre-specified for contrastive or brandnew elements. At the same time, there is the tendency to put the topic as far to

\footnotetext{
${ }^{4}$ This diagram type, also called a Hasse diagram, was originally developed for displaying poset relations (following the two rules: (1) If $x<y$ in the poset, then the point corresponding to $x$ appears lower in the drawing than the point corresponding to $y$, and (2) The line segment between the points corresponding to any two elements $x$ and $y$ of the poset is included in the drawing iff $x$ covers $y$ or $y$ covers $x$. (Skiena 1990), and is used in such different fields as chemistry and linguistics (e.g. Optimality Theory, to show the ranking of constraints). I make use of the following interpretation of the diagram, which differs slightly from the original: Each line is to be read as ' $\mathrm{x}$ is higher-ranked than $\mathrm{y}$ ', with $\mathrm{x}$ literally higher than $\mathrm{y}$.
} 
the left as possible. Possible conflicts between these requirements are solved as follows: If there are contrastive, scene-setting or brand-new elements present, they are moved into the Vorfeld. Only if no such elements are present can the $\mathrm{C}_{\mathrm{b}}$ be put into the Vorfeld. It is interesting to note that even if the Vorfeld is already occupied there is a tendency to put the $\mathrm{C}_{\mathrm{b}}$ as far to the front as possible, so that it occupies the first place in the Mittelfeld (i.e. the area between $\mathrm{C}^{\circ}$ and stranded $\mathrm{V}^{\circ}$-elements). If the $\mathrm{C}_{\mathrm{b}}$ is the subject, this position seems to be obligatory. This finding is expected, given two competing possibilities: that Vorfeldbesetzung in German could work along the lines of English inversion or along the lines of English topicalization.

Linking back to the question asked in the beginning whether German Vorfeldbesetzung is like English inversion or English topicalization, we can see that both views are true, but that when the two requirements - i.e. the requirements that lead to topicalization versus the ones that lead to inversion come into conflict, topicalization beats inversion/centering.

Abstracting away from the starting point, Centering Theory, we could state the following as the real conclusion of this paper: German Vorfeldbesetzung can serve four functions: (i) marking a backward-looking center; (ii) marking a scene-setting element; (iii) marking an element in P-kontrast with other elements; or (iv) marking new information which has been base-generated in a position disfavoured for new information. Each of these four functions is in English assigned a separate construction. That is, marking of a backwardlooking center is assigned inversion (under certain additional circumstances); marking of a scene-setting element can be assigned locative inversion; marking of an entity in a poset relation (which is more or less comparable to P-kontrast in German) is assigned topicalization; and marking of new information is assigned left-dislocation. What these English constructions share is that they all involve non-canonical word order and the constituent which is marked for the respective pragmatic function is moved to sentenceinitial position. For German it would be impossible to disambiguate these four constructions due to the verb-second constraint, which makes sure that only one constituent is moved to preverbal position so that a distinction between three constructions and a more or less 1-to-1 assignment of functions to these constructions as in English - both kinds of inversion with the word order X $\mathrm{V}-\mathrm{S}$; topicalization with the word order $\mathrm{X}-\mathrm{S}-\mathrm{V}$ and Left dislocation with the word order $X_{i}-S_{(i)}-V-Y_{(i)}-$ could not be made. Another way to look at this is that behind German Vorfeldbesetzung three potentially different constructions are hidden, which surface as the same construction due to a particularity of German syntax, viz. the verb-second constraint. To take a cross-linguistic view, one could say that German Vorfeldbesetzung combines the properties of three constructions which in other Germanic languages, like English, would be distinct from each other. 


\section{References}

Altmann, Hans. 1981. Formen der ,Herausstellung' im Deutschen. Niemeyer, Tübingen.

Birner, Betty J. 1998. Recency Effects in English Inversion. In Walker, Marilyn A., Aravind K. Joshi and Ellen F. Prince, eds., 1998a, pp. 310-323.

Culicover, Peter W. and Michael Rochemont. 1983. Stress and Focus in English. Language 59: 123-165.

Grewendorf, Günther, Fritz Hamm and Wolfgang Sternefeld. 1987. Sprachliches Wissen. Suhrkamp, Frankfurt/M.

Grosz, Barbara and Sidner, Candace. 1986. Attention, Intentions, and the Structure of Discourse. Computational Linguistics 12: 175-204.

Grosz, Barbara J., Aravind K. Joshi and Scott Weinstein. 1995. Centering: A Framework for Modelling the Local Coherence of Discourse. Computational Linguistics 21: 203-225.

Gundel, Jeanette K. 1985. 'Shared Knowledge' and Topicality. Journal of Pragmatics 9: 83107.

Hirschberg, Julia. 1985. A Theory of Scalar Implicature. PhD diss., University of Pennsylvania, Philadelphia.

Höhle, Tilman. 1982. Explikationen für 'normale Betonung' und 'normale Wortstellung'. In Abraham, Werner, ed., Satzglieder im Deutschen. Narr, Tübingen, pp. 75-153.

Jacobs, Joachim. 2001. The Dimensions of Topic-Comment. Linguistics 39: 641-681.

Lenerz, Jürgen. 1977. Zur Abfolge nominaler Satzglieder im Deutschen. Narr, Tübingen.

Molnár, Valéria. 1991. Das TOPIK im Deutschen und im Ungarischen. Almqvist och Wiksell, Stockholm.

Prince, Ellen F. 1981. Toward a Taxonomy of Given-New Information. In Peter Cole, ed., Radical Pragmatics. Academic Press, New York, pp. 223-255.

Prince, Ellen F. 1997. On the Functions of Left-Dislocation in English Discourse. In A. Kamio, ed., Directions in Functional Linguistics. John Benjamins, Amsterdam/ Philadelphia, pp. 117-143.

Prince, Ellen F. 1998. Subject Pro Drop in Yiddish. In P. Bosch and R. van der Sandt, eds., Focus: Linguistic, Cognitive and Computational Perspectives, Cambridge University Press, Cambridge, pp. 82-104.

Prince, Ellen F. 1999. How Not to Mark Topics: 'Topicalization' in English and Yiddish. Texas Linguistics Forum, University of Texas Press, Austin, chapter 8.

Rambow, Owen. 1993. Pragmatic Aspects of Scrambling and Topicalization in German: A Centering Approach. Ms., University of Pennsylvania.

Reis, Marga. 1987. Die Stellung der Verbargumente im Deutschen. Stilübungen zum Grammatik:Pragmatik-Verhältnis. In I. Rosengren, ed., Sprache und Pragmatik. Lunder Symposion 1986. Almqvist och Wiksell, Stockholm, pp. 139-177.

Reis, Marga. 2000. Anmerkungen zu Verb-erst-Satz-Typen im Deutschen. In R. Thieroff et al, eds., Deutsche Grammatik in Theorie und Praxis. Niemeyer, Tübingen, pp. 215-227.

Rochemont, Michael S. 1986. Focus in Generative Grammar. John Benjamins, Amsterdam/ Philadelphia.

Rochemont, Michael S. and Peter W. Culicover. 1990. English Focus Constructions and the Theory of Grammar. Cambridge University Press, Cambridge.

Skiena, Steven S. 1990. Implementing Discrete Mathematics: Combinatorics and Graph Theory with Mathematics. Addison-Wesley, Redwood City, CA.

Vallduví, Enric and Maria Vilkuna. 1998. On Rheme and Kontrast. In P. Culicover and L. McNally, eds., Syntax and Semantics 29: The Limits of Syntax. Academic Press, New York, pp. 79-108. 
Vikner, Sten. 1995. Verb Movement and Expletive Subjects in the Germanic Languages. Oxford University Press, Oxford/New York.

Walker, Marilyn A. 2000. Vers un modèle de l'interaction du Centrage avec la structure globale du discourse. Verbum 22: 31-58.

Walker, Marilyn A., Aravind K. Joshi and Ellen F. Prince. 1998a. Centering Theory in Discourse. Oxford University Press, Oxford/New York.

Walker, Marilyn A., Aravind K. Joshi and Ellen F. Prince. 1998b. Centering in Naturally Occurring Discourse: An Overview. In idem, eds. 1998a, pp. 1-28.

Whitton, Laura 2004. The Discourse Function of Topics in Late Middle English and Early Modern English and their Relationship to Subject-Verb Inversion. To appear in Penn Working Papers in Linguistics.

\section{Texts used as Corpus:}

\begin{tabular}{|c|c|c|c|c|}
\hline Genre of text & Examples & Sigillum & $\begin{array}{l}\text { Number } \\
\text { of } \\
\text { selections }\end{array}$ & $\begin{array}{l}\text { Number } \\
\text { of } \\
\text { sentences }\end{array}$ \\
\hline \multirow{2}{*}{ Literature } & $\begin{array}{l}\text { Günther Grass: Das Treffen } \\
\text { in Telgte }\end{array}$ & GrT & 3 & 68 \\
\hline & $\begin{array}{l}\text { Friedrich Dürrenmatt: Der } \\
\text { Richter und sein Henker }\end{array}$ & DüR & 4 & 61 \\
\hline \multirow{2}{*}{$\begin{array}{l}\text { Scientific } \\
\text { publications }\end{array}$} & $\begin{array}{l}\text { H. Krauss, ed.: Neues } \\
\text { Handbuch der } \\
\text { Literaturwissenschaft, vol. } 7\end{array}$ & $\mathrm{HL}$ & 2 & 36 \\
\hline & $\begin{array}{l}\text { J.Bumke: Geschichte der } \\
\text { deutschen Literatur im hohen } \\
\text { Mittelalter }\end{array}$ & DLM & 1 & 32 \\
\hline Newspaper & $\begin{array}{l}\text { Stuttgarter Zeitung (Feb. 22; } \\
28,2003 \text { ) }\end{array}$ & $\mathrm{StZ}$ & 6 & 188 \\
\hline $\begin{array}{l}\text { Scientific } \\
\text { presentations }\end{array}$ & $\begin{array}{l}\text { SWR2 Aula } \\
\text { (fromwww.swr2.de) }\end{array}$ & $\mathrm{Au}$ & 4 & 62 \\
\hline Letters & $\begin{array}{l}\text { Stuttgarter Zeitung (Feb. 21; } \\
24 ; 25,2003 \text { ) }\end{array}$ & $\mathrm{E}$ & 9 & 85 \\
\hline Radio text & $\begin{array}{l}\text { SWR2 Wissen (from } \\
\text { www.swr2.de) }\end{array}$ & $\mathrm{R}$ & 11 & 90 \\
\hline
\end{tabular}

